Journal of Contemporary Educational Research

Research Article

\title{
What Users and Uses of Englishes are Represented in the English Textbooks in China
}

\author{
Xiaofan Zhang ${ }^{1 *}$, Feiran Zhang ${ }^{2}$ \\ ${ }^{1}$ The Experimental High School Attached to Beijing Normal University, Beijing 100032, China \\ ${ }^{2}$ The Central Academy of Drama, Beijing 102209, China
}

\begin{abstract}
To explore the representation of users and uses of Englishes in the textbooks, a series of English textbooks for junior high school in China were examined in this study. Findings from analysis of representations of users and uses of Englishes were presented. The results show that China, the UK and the US are dominant in the representations of users. Outer circle countries and expanding countries (other than China) have no clear representations.

Key words: English teaching and learning; Users and uses of English; Textbooks, China

Publication date: September, 2020

Publication online: 30 September, 2020

*Corresponding author: Xiaofan Zhang, zxfletter@163. com
\end{abstract}

\section{Introduction}

In the era of globalization, English has spread rapidly and widely. It is used by more 'non-native speakers' than 'native speakers' (Scrivener, 2011). English is "no longer linked to a single culture or nation but serves both global and local needs" (McKay, 2002, p.24.) Learning English as an international language requires to "prepare the learners to use English to become part of the globalized world, which is linguistically and culturally diverse" (Matsuda, 2012, p.169).

China has the largest number of English learners in the world. English teaching and learning has developed rapidly in China. The New English Curriculum Standards in China (Ministry of Education, 2011) emphasize the development of cross-cultural awareness and intercultural communicative competence (Cheng,
2011). The textbooks in China are required to be designed on the basis of the New English Curriculum Standards, and are compulsory to use in public schools.

The goal of this study is to investigate how these textbooks reflect the diversity of users and uses of English

\section{Methodology}

\subsection{Sample}

In the research, English (2013) for junior high school students (in Grade 7 9, aged 13 15) was investigated. The series of books were locally produced and approved by Ministry of Education of the People's Republic of China. They are published by Foreign Language Teaching and Research Press, and are being taught nationwide (in Beijing, Zhejiang Province, Inner Mongolia, etc.) (Zhu, 2016). It was first released in1999, and the latest version, which is conducted as sample in this study, was written on the basis of the instruction from the new National English Curriculum Standards (MOE, 2011).

In this study, the textbooks for Grade 7 9 were examined, including 6 books: Books 7A and 7B for Grade 7, Books 8A and 8B for Grade 8, Books 9A and 9B for Grade 9. All the contents of these six books are organized in a similar structure. Each has 8 to 12 modules with different themes. In each module, there are dialogues. In the process of research, a total of 64 dialogues are examined.

\subsection{Data collection and analysis}

The research aims to investigate how these textbooks reflect the diversity of users and uses of English. 
Matsuda's (2002) model was adopted in this section. When evaluating ELT textbooks used in Japan, Matsuda (2002) identified the nationality of main characters in texts and divided them into different categories based on Kachru's (1985) classification of three circles (inner circle, out circle and expanding circles). Matsuda (2002) also identified in which country the communication in English happens, to analyze the contexts of English uses in term of 'three circles'. Besides, the types of English uses were investigated in Matsuda's (2002) study, and the analysis focused on whether the use is 'intra-national' or 'international'. 'Intra-national' refers to the communication between people from the same country, and 'international' means the communication between people from different countries.

According to the features of the ELT context in China, Matsuda's (2002) model was adapted and modified as following. In the dialogues from every module, the nationalities of the characters participating in dialogues were identified on the basis of their selfintroduction and other relative information. The representation of users included from (1) China, (2) the UK, (3) the US, (4) other inner circle countries, (5) outer and expanding circle countries (other than China),
(1) between Chinese and people from inner circle countries, (2) between Chinese and people from outer or expanding circle countries, (3) between people from different inner circle countries, (4) between people from different outer or expanding circle countries (other than China), (5) between people from inner circle countries and outer or expanding circle countries (other than China).

\section{Findings}

\subsection{Representations of users of Englishes}

In this series of textbooks, various representations of users of Englishes make dialogues in the main texts. Table 1 presents the nationality of the users and how many words they uttered.

Some characters only appear once in these books, while some characters repeatedly appear in each book. When counting the total number of the users, if one character presents across books, he/she was counted as 'one user'. For example, 'Daming' (a Chinese boy student), appeared in each book, from 7A to 9B, then in total number, he was counted as 'one' user instead of six.

Table 1. Nationality of users and the Number of the Words spoken by Them

*OI=other inner circle countries, $\mathrm{OE}=$ outer circle and other expanding circle countries (other than China)*

*Number of users (number of words)*

\begin{tabular}{ccccccccc}
\hline & China & the UK & the US & UK+US & OI & OE & Unknown & Sum \\
\hline Total & $10(4358)$ & $3(3060)$ & $3(2531)$ & $6(5591)$ & 0 & 0 & $5(883)$ & $21(10832)$
\end{tabular}

(6) unknown (not mentioned in the texts). The numbers of words spoken by each character were counted, and the character's jobs and roles in the communication were noted as well.

The contexts of English uses represented in the textbooks were identified according to the information about in which region the communication happens. In this study, the contexts included (1) China, (2) inner-circle countries, (3) outer and expanding circle countries (other than China), (4) on email or phone, (5) unknown (not mentioned in the texts).

The types of English uses involved intra-national use and international use. Three sub-categories in intra-national use: (1) between people from China, (2) between people from inner circle countries, (3) between people from outer or expanding circle countries (other than China). Five sub-categories in international use:
For nationality, among the 21 characters, the majority are from China (10) and the UK/ the US (6). No character can be identified from other inner circle countries, outer circle countries or expanding circle countries (other than China). In total, 5 characters' nationalities cannot be unambiguously identified, for example, a tourist in Beijing asked for directions without introducing or implying his nationality (Module 6 Unit 1 in Book 7B).

For the number of words, 10832 words were produced by all the characters. The characters from the UK/the US produced most (5591words), which is larger than the words that Chinese characters produced (4358 words).

It should also be noted that there are four characters that appear repeatedly in each book, they are Daming (Chinese boy), Lingling (Chinese girl), Tony (British 
boy) and Betty (American girl). They are classmates in a junior high school in Beijing, which means they are about the age of the students who use these textbooks. These four are the main characters in the dialogues, and conversations mostly happen between them, or between them and their teachers or family. To some extent, these characters 'grow up' with the students reading the textbooks, because the characters' experiences presented in each book could be similar with the student readers' experience from Grade 7 to Grade 9. For example, in Module 1 Unit 1 of Book 7A, the characters began their new school life and greeted to each other for the first time, and in Module 8 Unit 1 of Book 9B, they gave each other best wishes in the graduation ceremony.

\subsection{Representations of contexts of English uses}

This study also examined the contexts of English uses, i.e. where conversations happened. The numbers of conversations in the sampled textbooks are revealed in Table 2. they are all the dialogues between British or American people.

No English use in outer or expanding circle countries (other than China) is represented in this series of textbooks.

\subsection{Representations of types of English uses}

In the sampled textbooks, different types of intranational and international uses of English are represented in the 64 pieces of conversations. Table 3 illustrates the numbers of each type in this series of books. The majority of the conversations involve Chinese and people from inner circle countries. No conversation involves speakers from outer or expanding circle countries (other than China). There are 8 conversations of which the type cannot be categorized because the users' nationalities cannot be identified.

Compared to intra-national uses, international uses are represented far more commonly in each book and in total, with 45 out of 64 conversations happening

Table 2. Contexts of English Uses

* INN= inner circle countries, $\mathrm{OE}=$ outer circle and other expanding circle countries other than China ${ }^{*}$

\begin{tabular}{|c|c|c|c|c|c|c|}
\hline & Number of conversations & China & $\mathrm{INN}$ & $\mathrm{OE}$ & on Email or phone & Unknown \\
\hline Total & 64 & 56 & 6 & 0 & 1 & 1 \\
\hline
\end{tabular}

Table 3. Types of English Uses

* $\mathrm{CHN}=$ users from China, INN=users from inner circle countries*

\begin{tabular}{|c|c|c|c|c|c|c|}
\hline & \multirow{2}{*}{ Number of conversations } & \multicolumn{2}{|c|}{ International communication } & \multicolumn{2}{|c|}{ Intra-national communication } & \multirow{2}{*}{$\begin{array}{l}\text { Communication including } \\
\text { 'unknown users' }\end{array}$} \\
\hline & & CHN-INN & INN-INN & $\mathrm{CHN}$ & INN & \\
\hline Total & 64 & 43 & 2 & 2 & 9 & 8 \\
\hline
\end{tabular}

In the 64 pieces of conversations, three contexts are clearly presented: in China, in inner circle countries, on email of phone. Only the context of the conversation in Module 5 Unit 1 of Book 9A cannot be identified, because it happened in a museum, but it is not mentioned where the museum is.

$87.5 \%$ of the conversation are set in China. The main characters make dialogues in their junior high school in China, or they have conversations when visiting different places in China, for example the Great Wall (Module 9 Unit 1 in Book 7A).

English uses in inner circle countries are represented in 6 conversations in the books, and all of them happened in British or American families, which means between people from different countries. In these 45 conversations, 43 of them were presented by Chinese and people from inner circle countries, while only 2 of them were presented by people from different inner circle countries.

For intra-national uses of English, 9 conversations between speakers from the same inner circle countries are presented. All these conversations are presented by speakers from the UK or the US. With the analysis of context, 7 of them happened in family and another was made on the phone, and the other happened in railway station in China.

Two conversations may be set inappropriately, because they are the dialogues between Chinese people 
only. In Module 4 Uni1 in Book 8B, the dialogue was between a Chinese doctor and a Chinese patient, and in Module 3 Unit 1 in Book 9A, a Chinese teacher and a Chinese student talked about a Chinese hero. They may not be the appropriate example of the real use of English in real life, because it seldom happens that the conversations in English between Chinese people.

\section{Conclusion}

In this series of textbooks, the representations of British and American users are still dominant. Without the varieties in the representation of English users and uses, the textbooks may fail to help learners realize the significance of variety of English contributed by 'nonnative speakers' (Matsuda, 2002).

The settings of most dialogues in textbooks were in China and between Chinese and people from the UK and the US, which means learners may commonly use English in China with foreign visitors and international students. This may hinder students' idea of English used as lingua franca (Byram, Holmes, Savvides, 2013). The lack of varieties in the contexts of English use may fail to help students be prepared for the real use of English in different places of the world. No differences were presented in the main characters' use of English, which means even the speakers from different cultural groups, the features or habits of their expressions present no differences. This may fail to provide opportunities for students to understand the effectiveness and appropriateness in the cross-culture communication (Wiseman, Hammer, and Nishida, 1989).

However, in this study, only one series of textbooks were examined. Even if they were widely used in China, it is still possible that the sampled textbooks fail to reflect all the common features which the English textbooks in China share. Besides, this series are used in junior high school, and the textbooks in primary school, senior high school and collage may present different feature. If the sample including the textbooks used in every grade, the study would better reflect the English learning and teaching system in China. Moreover, the comparison and contrast with English textbooks in other countries or the globally used English textbooks may contribute to a better understanding the features of Chinese textbooks.

\section{Sampled textbooks:}

Chen, L., Greenall, S., eds., 2013. English. Beijing: Foreign Language Teaching and Research Press.

\section{References:}

[1] Byram, M., Holmes, P., and Savvides, N., 2013. Intercultural communicative competence in foreign language education: questions of theory, practice and research. The Language Learning Journal, 41(3), pp. 251-253.

[2] Cheng, X., 2011. The 'English curriculum standards' in China: rationales and issues. In: A. Feng, ed. English Language Education Across Greater China. Bristol: Multilingual Matters, pp. $133-150$.

[3] Kachru, B.,1985. Standards, codification and sociolinguistic realism: The English language in the outer circle. In R. Quirk, H. Widdowson eds. English in the world. London: Longman., pp. 11-32.

[4] Matsuda, A., 2002. Representation of users and uses of English in Beginning Japanese EFL textbooks. JALT Journal, 24(2), pp. 182-216

[5] Matsuda, A., 2012. Teaching Material in EIL. In: L. Alsagoff, S. L. McKay, G. Hu, W.A. Renandya, ed. Principles and practices for teaching English as an international language. Hoboken: Taylor and Francis, pp. 168-185

[6] McKay, S. L., 2002. Teaching English as an international language: Rethinking goals and approaches. Oxford: Oxford University Press.

[7] Ministry of Education (MOE), 2001. English Curriculum Standards (for 9-year compulsory education and senior high schools). Beijing: Beijing Normal University Press. (In Chinese).

[8] Scrivener, J., 2011. Learning teaching -the essential guide to English language teaching. 3rd ed. Oxford: Macmillan.

[9] Wiseman, R. L., Hammer, M. R. and Nishida, H., 1989. Predictors of intercualutral communication competence. International Journal of Intercultural Relations, 13(3), pp. 349-370.

[10] Zhu, Y., 2016. The current situation of EFL textbooks for junior high school in China and the suggestions for educational reformation. Teaching and Management, 2016(7), pp. 83-85. (In Chinese) 